\title{
Autologous Blood Injection Therapy for tendinopathy
}

\author{
Olga Frankowski \\ From Society of Chiropodists and Podiatrists Annual Conference 2010 \\ Bournemouth, UK. 21-23 October 2010
}

\section{Introduction}

The aim of this poster is to provide a rationale and critical overview of 'Autologous Blood Injection Therapy' a new and possibly superior treatment modality in the management of tendinopathy. The theoretical background will be appraised including its clinical application and perceived clinical effectiveness.

\section{Methods}

literature review and critical appraisal of papers

\section{Results}

Autologous blood injection therapy has been shown to have a significant positive effect on both pain and joint function, with concomitant therapies not being demonstrated to be required in the management of tendinopathy. However, the majority of studies were representative of patients being treated for refractory epicondylitis with different procedure techniques being employed. No studies compared blood re-injection therapy with dry needling alone, with minimal data available from controlled studies preventing a placebo response from being ruled out.

\section{Discussion}

With current evidence on the efficacy of autologous blood injection therapy in the management of tendinopathy being insufficient in quantity and quality, the current National Institute for Health and Clinical Excellence guidelines state this procedure is to only be used with special arrangement. Future research should focus on randomised control trials that clearly describe previous or adjunctive therapeutic interventions with a minimum follow up of 1 year.

University of Salford, Salford, Greater Manchester, UK
Published: 20 December 2010

doi:10.1186/1757-1146-3-S1-P11

Cite this article as: Frankowski: Autologous Blood Injection Therapy for tendinopathy. Journal of Foot and Ankle Research 2010 3(Suppl 1):P11.
Submit your next manuscript to BioMed Central and take full advantage of:

- Convenient online submission

- Thorough peer review

- No space constraints or color figure charges

- Immediate publication on acceptance

- Inclusion in PubMed, CAS, Scopus and Google Scholar

- Research which is freely available for redistribution

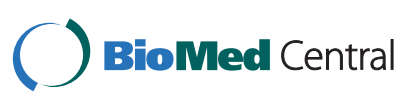

(c) 2010 Frankowski; licensee BioMed Central Ltd. This is an open access article distributed under the terms of the Creative Commons Attribution License (http://creativecommons.org/licenses/by/2.0), which permits unrestricted use, distribution, and reproduction in any medium, provided the original work is properly cited. 